\title{
Depression and Quality of Life in People with Systemic Lupus Erythematosus
}

\author{
Fitria Maharani Harsono Putri and Magdalena S. Halim \\ Graduate Program of Professional Psychology \\ Atma Jaya Catholic University of Indonesia
}

\begin{abstract}
The aim of this research was to determine the relationship between depression and some aspects of the quality of life. As additional data, the researchers sought connections between demographic factors and the quality of life. This research used measurement implements in the form of the Beck Depression Inventory-II (BDI-II) and the LupusQoL. The participants involved in the research were 49 females aged between 18 and 45 years. The results of the research indicated that depression has a significant relationship with all aspects of quality of life, with the exception of the aspect of body image. The greater the depression, the worse the quality of life. Conversely, the lighter the depression, the better the quality of life. Besides this, the research also indicated a significant difference in aspects of the quality of life, on the basis of demographic factors. The conclusion from the research is that depression is an important matter for attention. By overcoming depression, a number of aspects of the quality of life of people with Lupus/SLE may be improved.
\end{abstract}

Keywords: depression, quality of life, people with Lupus, Systemic Lupus Erythematosus (SLE)

Tujuan penelitian ini adalah untuk mengetahui hubungan depresi dengan aspek-aspek dalam kualitas hidup. Sebagai data tambahan, peneliti mencari hubungan antara faktor demografi dengan kualitas hidup. Penelitian ini menggunakan alat ukur berupa the Beck Depression Inventory-II (BDI-II) dan LupusQoL. Partisipan yang terlibat dalam penelitian ini berjumlah 49 orang wanita yang berusia 18-45 tahun. Hasil penelitian menunjukkan bahwa depresi memiliki hubungan yang signifikan dengan seluruh aspek dalam kualitas hidup, kecuali aspek body image. Semakin berat depresi maka kualitas hidup semakin buruk, sebaliknya semakin ringan depresi maka kualitas hidup semakin baik. Faktor demografi menunjukkan tidak adanya hubungan dengan aspek-aspek dalam kualitas hidup. Kesimpulan dari penelitian ini adalah depresi yang penting untuk diperhatikan. Dengan mengatasi depresi, maka dapat meningkatkan kualitas hidup Orang dengan Lupus/SLE pada berbagai aspek.

Kata kunci: depresi, kualitas hidup, orang dengan Lupus, Systemic Lupus Erythematosus (SLE)

SLE is an auto-immune disease, which may attack body organs, and is of unknown etiology (Lahita, Tsokos, Buyon, \& Koike, 2011). To date, SLE is incurable, but treatments for SLE can reduce the symptoms which have appeared and the damage to organs. Differing from other diseases, SLE can trigger bigger chances for people with SLE suffering psychological pressure, because of a number of problems, beginning with diagnosis, which is difficult to establish, on the basis of the symptoms, which resemble those of other diseases, through the unpredictable progression of di-

Correspondence concerning this article should be addressed to Fitria Maharani Harsono Putri, Graduate Program of Professional Psychology, Atma Jaya Catholic University of Indonesia, Jenderal Sudirman 51, Jakarta 12930. E-mail: mhpfitria@gmail.com sease, to an inaccurate understanding by society of people with SLE, because sufferers of SLE appear to be people who are not suffering chronic disease.

Additionally, there are other problem which may be experienced by people with SLE in their daily lives, these being problems of cognitive function (Kasjmir et al., 2011; Wallace, 2007), fertility problems for both men and women (Gayed \& Gordon, 2007), self-esteem problems, difficulties in employment, lifestyle changes, such as a need to sleep or have more rest than is considered usual (Al Dhanhani, Gignac, Beaton, Su, \& Fortin, 2014; Tay, Cheung, \& Mak, 2015). They also suffer hardships in carrying out daily activities. These problems can cause a sense of hopelessness, which can lead to depression. 
Seventeen studies conducted in several countries showed that depression in people with SLE as rating between 17 and 75\% (Palagini et al., 2013). Meanwhile, in Indonesia, an internist who is also a specialist regarding SLE, Prof. dr. Zubairi Djoerban SpPDKHOM, has revealed that about $40 \%$ of people with SLE in Indonesia have depression, or psychological disorders, such as prolonged sadness owing to the changes they suffer causing depression ("Lupus yang Misterius," 2008). Previous studies in Indonesia showed that $90 \%$ of them suffered mild depression, while the rest of them suffered moderate to severe depression (Hidayati, 2014).

Beck (as cited in McDowell, 2006) defines depression as a mood disorder, which is characterized by emotional, cognitive, motivational, and physical signs or symptoms. In fact, depression is a normal reaction to negative experiences, such as disappointment or loss. Depression then becomes abnormal if it manifests at high intensity, continuously, until becoming permanent. In people with a chronic disease, such as SLE, depression is a normal emotional reaction, especially when such people have recently been diagnosed with SLE. However, it may last longer if it is not resolved, and have various other impacts, leading to further deterioration, difficulties in carrying out responsibilities or roles in life, to the extent it disturbs daily activities.

The many psychological pressures experienced by people with SLE may affect their ability to perform their functions, and also have an impact on their quality of life (Buckhardt, Archenholtz, \& Bjelle; Buckhardt, Archenholtz, Mannerkorpi, \& Coyne; Fitzpatrick, Newman, Lamb, \& Shipley, as cited in Seawell \& Danoff-Burg, 2005). Therefore, psychological pressure, in form of uncontrollable depression, is an important factor to be considered for people with SLE, because it has a negative impact on their quality of life.

This quality of life is the perspective of people with SLE regarding their well-being, in the aspects of physical health, pain, planning, intimate relationships, being a burden to others, emotional health, body image, and fatigue (McElhone et al., 2007). In general, several previous studies have shown that depression is related to quality of life (Balsamo et al., 2013; Petterson et al., 2015; Shen et al., 2013).

In particular, previous studies have shown differrent correlations between depression and aspects of quality of life. Studies have shown that depression has a correlation to feeling one is a burden to others, fatigue (O'Riordan, Doran, \& Connolly, 2017) and body image (O'Riordan et al., 2014). Results show- ing a feeling of being a burden to others, fatigue, and poor emotional health was revealed in research by Etchegaray-Morales et al., 2017.

This indicates that depression is correlated to feeling of tiredness, negatives emotions, negative appraisal regarding appearance, and a feeling of becoming a burden for those around one. The differences in the results from studies in various countries become an important focus for study, to determine the correlation between depression and aspects of quality of life for people with SLE, in Indonesia. Furthermore, by determining such a correlation, it may be used as a reference to conduct efficacious treatment to reduce depression, and thus improve the quality of life for people with SLE in Indonesia. Based on this, the researchers were interested to examine the correlation between depression and the aspects of physical health, pain, planning, intimate relationships, feeling of being a burden to others, and fatigue, for the quality of life of people with SLE.

\section{Method}

This study is one of correlational research with a quantitative approach. This approach is used to examine the correlation between depression and aspects of the quality of life. The researchers also used convenience sampling, as a research sampling technique. This study has obtained ethical clearance approval from the Institute of Research and Community Service of Atma Jaya Catholic University of Indonesia. Each participant was given information explaining informed consent, before filling out the questionnaire. Participants filled out the questionnaires while waiting for their doctor's examinations schedules or during a visit to the Yayasan Lupus Indonesia (the Indonesian Lupus Institute - YLI). There were no time limits imposed on those completing the questionnaires. Furthermore, because the data was abnormally distributed, the researchers conducted a Spearman non-parametric correlation test, to assess the relationship between depression and each aspect of quality of life. Additionally, researchers conducted a Chi-Square statistical test, to examine the relationships between demographic factors and each aspect of quality of life.

\section{Participants}

The participant involved in this study comprised of 49 women, diagnosed with SLE, aged from 18 to 45 years $\left(M_{\text {age }}=31.42 ; S D_{\text {age }}=6.63\right)$. Participants in this 
study had to be in remission, or in a condition where they were able to perform daily activities, whilst still taking medication or undergoing other treatment, to have as a minimum a primary school education, and so have the ability to understand the questionnaire, to suffer no severe physical problems nor currently be undergoing hospital treatment, and not to have been diagnosed with psychological disorder, by a psychiatrist or psychologist. This research was conducted at the Yayasan Lupus Indonesia (YLI), Jakarta in MarchApril 2017.

\section{Measurement}

BDI-II (the Beck Depression Inventory-II), Indonesian version. The BDI-II (Ginting, Näring, van der Veld, Srisayekti, \& Becker, 2013) consists of 21 statements used to determine signs or symptoms of depression. The BDI-II, Indonesian version, has a convergence construct validity value of .52 with a DS14 (Type D Scale) and a BAI (Beck Anxiety Inventory), which shows that the BDI-II has constructs which are significantly aligned with the DS14 and the BAI, and a discriminant of - 0.39 with a MSPSS (Multi-dimensional Scale of Perceived Social Support) and - 0.46 with the LOT-R (Life Orientation Test- Revised) which shows that the constructs of the BDI-II are not aligned with the constructs of the MSPSS and the LOT-R (Ginting et al., 2013). Moreover, the Indonesian version of BDI-II has a reliability score of .90 (Ginting et al.). Each response is scored on a scale from 0 (not) to 3 (severe). The range of total scores is from 0 to 63, with the categories comprising 0 to 9 (no/minimal depression), 10 to 18 (mild depression), 19 to 29 (moderate depression), and 30 to 63 (severe depression). The higher the score, the more severe the depression is experienced.

LupusQoL (Lupus Quality of Life). The LupusQoL (McElhone et al., 2007) comprises 34 statements, used to measure the quality of life of people with SLE, and includes eight aspects, these being, physical health, pain, planning, intimate relationships, emotionnal health, feeling of being a burden to others, body image, and fatigue. The LupusQoL was adapted into the Indonesian language and applied to 49 people, regarding these aspects, and to 39 people regarding aspects of intimate relationships. Especially regarding the intimate relationship aspect, participants who did not have a partner were free to abstain from answering the questions.

The LupusQoL Indonesian version shows values of validity coefficients ranging from .385 to .762 for the physical health aspect, .391 to .628 for the pain aspect, .672 to .725 for the planning aspect, .945 for the intimate relationships aspect, .620 to .790 for the feeling of being a burden to others aspect, .642 to .867 for the emotional health aspect, .528 to .706 for the body image aspect, and .338 to .392 for the fatigue aspect (the $r_{\text {table }}$ for intimate relationships was .316 , and the $r_{\text {table }}$ for all other aspects was .282). In addition, the LupusQoL, Indonesian version, has a reliability value of .862 for the physical health aspect, .682 for the pain aspect, .833 for the planning aspect, .972 for the intimate relationships aspect, .835 for the feeling of being a burden to others aspect, .909 for the emotional health aspect, .805 for the body image aspect, and .586 for the fatigue aspect. Each response is scored on a scale from 0 to 4 (all of the time $=0$; most of the time $=1$; a good bit of the time $=2$; occasionally $=3$; and never $=4$ ). The mean raw aspect score is transformed by dividing by four and multiplying by 100 . The range of total scores is from 0 100 , the higher the score, the better the quality of life and the lower the score, the worse the quality of life.

\section{Results}

Table 1 shows that the majority of participants were married (63\%), using the state-owned Badan Penyelenggara Jaminan Sosial (Social Insurance Administration Organization - BPJS) for medical insurance (80\%), have had relapses (75\%), and have no comorbidities, suffering only SLE (78\%). In addition, the number of participants who were in work was nearly the same as the number of participants out of work, and the number of participants who have suffered the disease for less than five years was nearly the same as the number who had suffered for more than five years. Besides this, descriptive data on depression showed that $43 \%$ of participant had no or minimal depression, $35 \%$ had mild depression, $14 \%$ had moderate depression, and $8 \%$ had severe depression. Additionally, the study also showed that $86 \%$ of participants had good quality of life regarding the aspect of physical health, $88 \%$ had good quality of life regarding the aspect of pain, $88 \%$ had good quality of life regarding planning, $92 \%$ of participants had a quality of life in the aspect of intimate relationship, $73 \%$ had good quality of life regarding feelings of being a burden to others, $78 \%$ had good quality of life regarding emotional health, $84 \%$ had good quality of life regarding body image, and $82 \%$ had good quality of life regarding fatigue. 
Table 1

Demographic Data of Participants

\begin{tabular}{|c|c|c|}
\hline Demographic & $\begin{array}{c}\mathrm{F} \\
(N=49)\end{array}$ & Percentage \\
\hline \multicolumn{3}{|l|}{ Marital Status } \\
\hline Married & 31 & $63 \%$ \\
\hline Single & 18 & $37 \%$ \\
\hline \multicolumn{3}{|l|}{ Education } \\
\hline High School & 18 & $37 \%$ \\
\hline Diploma & 9 & $18 \%$ \\
\hline Bachelor Degree & 20 & $41 \%$ \\
\hline Masters Degree & 2 & $4 \%$ \\
\hline \multicolumn{3}{|l|}{ Occupation } \\
\hline Employed & 23 & $47 \%$ \\
\hline Unemployed & 26 & $53 \%$ \\
\hline \multicolumn{3}{|l|}{ Treatment Payment } \\
\hline Government (BPJS) & 39 & $80 \%$ \\
\hline Personal & 10 & $20 \%$ \\
\hline \multicolumn{3}{|l|}{ Duration of Disease } \\
\hline$\leq 5$ years & 28 & $57 \%$ \\
\hline$>5$ years & 21 & $43 \%$ \\
\hline \multicolumn{3}{|l|}{ Relapse Frequency } \\
\hline Never Relapsed & 17 & $35 \%$ \\
\hline Relapsed & 32 & $75 \%$ \\
\hline \multicolumn{3}{|l|}{ Comorbidity } \\
\hline With comorbidity & 11 & $22 \%$ \\
\hline Without comorbidity & 38 & $78 \%$ \\
\hline
\end{tabular}

Based on the results of the correlation test in Table 2 , it was indicated that depression had a significant negative correlation with emotional health $(r=-.629$, $\rho<.01)$ with effect size $R^{2}=.395$, fatigue $(r=-.493$, $\rho<.01)$ with effect size $R^{2}=.243$, feeling of being a burden to others $(r=-.471, \rho<.01)$ with effect size Idem $R^{2}=.221$, pain $(r=-.381, \rho<.01)$ with effect size $R^{2}=.145$, physical health $(r=-.372, \rho<.01)$ with effect size $R^{2}=.138$. This means that the more severe the depression, the worse the quality of life, in the emotional health, fatigue, feeling of being a burden to others, pain, and physical health aspects. Conversely, the milder the depression, the better the quality of life, in the emotional health, fatigue, feeling of being a burden to others, pain, and physical health aspects.

Depression also had significant negative correlation with intimate relationships $(r=-.379, \rho<.05)$, with effect size $R^{2}=.143$, and planning ( $r=-.305, \rho$
$<.05$ ), with effect size $R^{2}=.093$. This indicated that the more severe the depression for people with SLE, the worse the quality of life regarding the intimate relationships and planning aspects, and, conversely, the milder the depression, the better the quality of life, for both aspects. Besides this, the correlation test results indicated that depression does not have a significant correlation with the aspect of body image.

Based on the above results, it may be concluded that any depression associated with the perspective of participants regarding their own wellbeing related to their SLE disease, in many aspects, except for the perspective of body image. However, depression had a strong correlation with the intimate relationships aspect, compared to other aspects, which had a moderate correlation, wherein $r=.30$ shows a moderate to medium correlation and $r=.50$ shows a strong or high correlation (Corder \& Foreman, 2009). Likewise, depression can explain the emotional health aspect of $39.5 \%$. This means that the depression in people with SLE is most strongly correlated with their perspective regarding their own condition, related to feelings, appears to be attributable to SLE disease, such as anger, disgust, sadness, anxiety, worry and lack of self-confidence. The more severe the depression experienced by people with SLE, the worse their perspective regarding their SLE disease.

\section{Additional Analysis}

The results in Table 3 show that there were significant differences in some aspects of quality of life attributable to demographic factors. There was a significant difference in the quality of life in the pain aspect, regarding payment for treatment $(U=128.5, \rho$ $<.05)$. Based on rank, the people within the SLE group who pay for treatment at personal cost had better quality of life from the pain aspect (mean rank $=32.32$ ) than the group of people with SLE who used the government insurance (BPJS) (mean rank $=22.88$ ). Furthermore, there was significant differences for quality of life in the physical health $(U=145.5, \rho<.05)$ and planning aspects $(U=170, \rho<.05)$ regarding relapse frequency. The group who had never suffered

Table 2

Spearman's Correlation Between Depression and Aspects of Quality of Life

\begin{tabular}{|c|c|c|c|c|c|c|c|c|}
\hline & $\begin{array}{c}\text { Physical } \\
\text { Health }\end{array}$ & Pain & Planning & $\begin{array}{c}\text { Intimate } \\
\text { Relationship }\end{array}$ & $\begin{array}{c}\text { Burden to } \\
\text { Others }\end{array}$ & $\begin{array}{c}\text { Emotional } \\
\text { Health }\end{array}$ & $\begin{array}{l}\text { Body } \\
\text { Image }\end{array}$ & Fatigue \\
\hline Depression & $\begin{array}{l}-.372^{* *} \\
\rho=.009\end{array}$ & $\begin{array}{l}-.381 * * \\
\rho=.007\end{array}$ & $\begin{array}{l}-.305^{*} \\
\rho=.033\end{array}$ & $\begin{array}{c}-.379 * \\
\rho=.017\end{array}$ & $\begin{array}{l}-.471 * * \\
\rho=.001\end{array}$ & $\begin{array}{l}-.629 * * \\
\rho=.000\end{array}$ & $\begin{array}{c}-.257 \\
\rho=.074\end{array}$ & $\begin{array}{l}-.493 * * \\
\rho=.000\end{array}$ \\
\hline
\end{tabular}


Table 3

Mann-Whitney U Test, Between Demographic Data and Aspects of Quality of Life

\begin{tabular}{|c|c|c|c|c|c|c|c|c|}
\hline & $\begin{array}{l}\text { Physical } \\
\text { Health } \\
(N=49)\end{array}$ & $\begin{array}{c}\text { Pain } \\
(N=49)\end{array}$ & $\begin{array}{l}\text { Planning } \\
(N=49)\end{array}$ & $\begin{array}{c}\text { Intimate } \\
\text { Relationships } \\
(N=39)\end{array}$ & $\begin{array}{l}\text { Burden to } \\
\text { Others } \\
(N=49)\end{array}$ & $\begin{array}{l}\text { Emotional } \\
\text { Health } \\
(N=49)\end{array}$ & $\begin{array}{c}\text { Body } \\
\text { Image } \\
(N=49)\end{array}$ & $\begin{array}{l}\text { Fatigue } \\
(N=49)\end{array}$ \\
\hline Marital Status & & & & & & & & \\
\hline $\begin{array}{l}\text { Married } \\
\text { Single }\end{array}$ & $\begin{array}{c}250.5 \\
\rho=.553\end{array}$ & $\begin{array}{c}267 \\
\rho=.799\end{array}$ & $\begin{array}{c}228.5 \\
\rho=.287\end{array}$ & $\begin{array}{c}111.5 \\
\rho=.286\end{array}$ & $\begin{array}{c}274.5 \\
\rho=.925\end{array}$ & $\begin{array}{c}264 \\
\rho=.754\end{array}$ & $\begin{array}{c}223 \\
\rho=.244\end{array}$ & $\begin{array}{c}250.5 \\
\rho=.550\end{array}$ \\
\hline Occupation & & & & & & & & \\
\hline $\begin{array}{l}\text { Employed } \\
\text { Unemployed }\end{array}$ & $\begin{array}{c}288.5 \\
\rho=.833\end{array}$ & $\begin{array}{c}267 \\
\rho=.513\end{array}$ & $\begin{array}{c}267 \\
\rho=.514\end{array}$ & $\begin{array}{c}163 \\
\rho=.563\end{array}$ & $\begin{array}{c}206 \\
\rho=.060\end{array}$ & $\begin{array}{c}280 \\
\rho=.702\end{array}$ & $\begin{array}{c}294.5 \\
\rho=.928\end{array}$ & $\begin{array}{c}257.5 \\
\rho=.401\end{array}$ \\
\hline $\begin{array}{l}\text { Payment for Treatment } \\
\text { BPJS } \\
\text { Personal }\end{array}$ & $\begin{array}{c}168 \\
\rho=.325\end{array}$ & $\begin{array}{c}128.5 \\
\rho=.049\end{array}$ & $\begin{array}{c}204.5 \\
\rho=.913\end{array}$ & $\begin{array}{c}94.5 \\
\rho=.530\end{array}$ & $\begin{array}{c}203.5 \\
\rho=.894\end{array}$ & $\begin{array}{c}193 \\
\rho=.700\end{array}$ & $\begin{array}{c}144.5 \\
\rho=.121\end{array}$ & $\begin{array}{c}176 \\
\rho=.424\end{array}$ \\
\hline $\begin{array}{l}\text { Duration of Disease } \\
\quad \leq 5 \text { years } \\
\quad>5 \text { years }\end{array}$ & $\begin{array}{c}275.5 \\
\rho=.708\end{array}$ & $\begin{array}{c}277.5 \\
\rho=.733\end{array}$ & $\begin{array}{c}256 \\
\rho=.435\end{array}$ & $\begin{array}{c}128 \\
\rho=.088\end{array}$ & $\begin{array}{c}278 \\
\rho=.744\end{array}$ & $\begin{array}{c}256.5 \\
\rho=.446\end{array}$ & $\begin{array}{c}264 \\
\rho=.543\end{array}$ & $\begin{array}{c}291.5 \\
\rho=.959\end{array}$ \\
\hline $\begin{array}{l}\text { Relapse Frequency } \\
\text { Never } \\
\text { Relapsed } \\
\text { Comorbidity }\end{array}$ & $\begin{array}{c}145.5 \\
\rho=.008\end{array}$ & $\begin{array}{c}219.5 \\
\rho=.260\end{array}$ & $\begin{array}{c}170 \\
\rho=.029\end{array}$ & $\begin{array}{c}137.5 \\
\rho=.461\end{array}$ & $\begin{array}{c}235.5 \\
\rho=.439\end{array}$ & $\begin{array}{c}246.5 \\
\rho=.590\end{array}$ & $\begin{array}{c}190.5 \\
\rho=.086\end{array}$ & $\begin{array}{c}211.5 \\
\rho=.199\end{array}$ \\
\hline $\begin{array}{l}\text { Present } \\
\text { Not present }\end{array}$ & $\begin{array}{c}187 \\
\rho=.597\end{array}$ & $\begin{array}{c}195.5 \\
\rho=.741 \\
\end{array}$ & $\begin{array}{c}201 \\
\rho=.845\end{array}$ & $\begin{array}{c}120 \\
\rho=.437\end{array}$ & $\begin{array}{c}208.5 \\
\rho=.990\end{array}$ & $\begin{array}{c}158 \\
\rho=.219\end{array}$ & $\begin{array}{c}141.5 \\
\rho=.104\end{array}$ & $\begin{array}{c}142 \\
\rho=.105\end{array}$ \\
\hline
\end{tabular}

a relapse had a better quality of life in the physical health aspect (mean rank $=32.44$ ) than the group who had experienced a relapse (mean rank $=21.05$ ) and the group who had never experienced a relapse had better quality of life in the planning aspect (mean rank $=31$ ) than the group who had experienced a relapse ( mean rank $=21.81$ ). There were no significant differences in other aspects and demographic factors.

\section{Discussion}

The more severe the depression experienced by people with SLE, the worse the quality of life is for the emotional health, feeling of being a burden to others, fatigue, pain, physical health, intimate relationships, and planning aspects. Conversely, the milder the depression for people with SLE, the better the quality of life for those seven aspects. This suggests that more severe depression leads to a worse quality of life regarding physical, psychological and social characteristics, accompanied by an inability by SLE sufferers perform their normal functions.

This finding is in accordance with the review by McElhone, Abbott, and Teh (2006) of 53 studies, the results of one of which reported that depression is a strong variable in predicting quality of life for people with SLE. People with SLE who can overcome depression showed that they may have good quality of life. Conversely, an unidentified and unresolved depression leads to a poor quality of life. This is also confirms the previous studies, which showed that the more severe the depression, the worse the quality of life for people with SLE (Balsamo et al., 2013; Petterson et al., 2015; Shen et al., 2013).

However, contrary to some of the previous studies (Deviliers et al., 2014; Etchegaray-Morales et al., 2017), in this study, the researchers found that depression had a significant correlation with seven aspects of the quality of life, but had no significant correlation with the body image aspect. This means that depression does have a significant impact on poor perspectives regarding their physical appearance, for people with SLE. This difference seems to be inseparable from the role of cultural factors in Indonesia.

All participants in the study were female, and the majority of participants wore the hijab (a veil traditionally worn by Muslim women) so that their daily clothes covered most parts of their bodies, except the face. The physical appearance affected by SLE was not a problem, because the red skin rash, body shape effects, and hair loss can be covered by the clothes worn. This made the effects of SLE on their physical bodies unknown to others, so there was no negative view from others making them evade social situations, or feel less attractive. This is one important consideration, considering the majority of Indonesian populace professes Islam, around $87.18 \%$ (Na'im \& Syaputra, 2010). 
Another consideration is that the rash or spots which typically appear on the face and take the form of butterflies - also called the 'butterfly rash' - were not visible with any of the participants in this study. Some of participants were seen to have black or brownish rashes on their faces, but they were not too obvious, and not butterfly-shaped, but showed as only a few spots. Other participants had red rashes on other parts of the body, such as on the arms, but these could be covered with long-sleeved clothing.

In another difference from several previous studies (Etchegaray-Morales et al., 2017; O'Riordan et al., 2017) it was found that depression had a significant correlation with aspects of pain, physical health, intimate relationships and planning. The pain caused by SLE is a problem considered important by people with SLE, because it really obstruct them from conducting their daily activities, especially when they are required to perform their roles as wives and mothers. Also, intimate relationships with a partner are an important problem for people with SLE. Participants felt that the more signs or symptoms of depression experienced as a result of pain, which may appear suddenly, the more they lose the interest in sexual relationships. Signs or symptoms of depression occurring owing to SLE also make difficulties for people with SLE to manage their lives, such as when making plans to meet other people, or attend events.

However, in this study, the aspects of intimate relationships and planning had a lower correlation coefficient, compared to other aspects of the quality of life. This may be caused by participants interpreting the items relating to the intimate relationships aspect as enquiring about just physical relationships with the partner, whereas other participants complained about emotional problems with their partners. Some participants also felt that making plans to meet others, especially friends with SLE, was a fun thing. Although they felt sadness because of their illnesses, meeting friends with SLE at some events can enable them to support each other, sharing stories about SLE and daily life.

Depression had the most significant correlation with the emotional health aspect, compared to other aspects of quality of life. People with SLE, who had depression, showed various other signs or symptoms of depression, also related to aspects of emotional health, such as: feelings of sadness, feeling there was no longer fun in their lives, directly or indirectly feeling anxious and worrying, caused by SLE. This suggests a more firm correlation between depression and the emotional aspects of health, because both variables contain emotional components. The firmness of the correlation between depression and the fatigue aspect may also be owing to some depression measurement statements in the questionnaire, which measured the same things as the fatigue aspects, such as lack of concentration, feeling of tiredness, and the need for longer sleep time. A significant correlation between depression and the feeling of being a burden to others aspect may be brought about in people with SLE who feel that their spouses left them, tired of taking care of them, when they experienced a decline in physical condition and were subject to sudden mood changes.

This study also found that there were significantly different aspects regarding the quality of life related to demographic factors. There was a significantly different quality of life related to the pain aspect, related to payment for treatment. The extent of the relationship between payment for treatment and quality of life depends on the availability of health care facilities in each country (McElhone, 2006). In this study, people with SLE who personally pay medication and treatment costs reported a better quality of life for the pain aspect than those who utilized government insurance or the BPJS. Although the costs of the main drugs needed were covered, there were some other things not covered by government insurance, such as laboratory examinations or other needed drugs. This made people reliant on the BPJS feel a lot of pain. Besides that, the longer wait time to consult a doctor than that experienced by other people, who paid personally, was also a problem and involved those utilizing the BPJS to suffer pain for longer periods.

Another significant finding in this study was that people with SLE, who had never suffered a relapse, had a better quality of life for aspects of physical health and planning. Never having suffered a relapse made them have the perspective that they were able independently to engage in various physical activities, without anyone's help, and were able to make plans to attend events or meet other people. Meanwhile, there were no significant differences in other aspects and demographic factors, such as marital status. This is confirmed by a previous study (McElhone, 2010), which indicated that there were no significant differences in quality of life related to marital status.

\section{Limitations of the Study}

One limitation with this study was that all the participants in this study were female, so that it was not possible to obtain data regarding whether there is any difference depression and quality of life for different genders. Based on various data, about $90 \%$ of 
people with SLE in the world are female (Wallace, 2007). During the data collection process for this study, there were no male people with SLE who consulted the doctors in the hospital associated with the YLI foundation, or who visited the foundation. That fact, plus the sample size, makes it necessary to be careful not to generalize the results. Other limitations in this study are technical problems, such as participants having to utilize crowded waiting rooms, there being no other empty rooms which might have been used at the time. This caused some participants to be less focused, while working on the questionnaire. Such conditions may have an effect on the perceptions of people with SLE, regarding their quality of life and signs or symptoms of depression experienced. For future research, it would be preferable to ensure that all participants enjoy the same conditions, while working on the questionnaire.

Additionally, modifying measurement via an indepth interview might be needed for future research, to identify other problems for people with SLE. This study found that emotional and intimate problems with a partner caused much concern for participants. The intimate relationship aspect can be defined as both physical and emotional closeness with a partner. However, a statement using the term "sexual relationship" can be interpreted only as a relationship involving physical contact with a partner. Especially in the context of Indonesian society, sexual relationships are often seen as relationship involving only physical aspects. A deeper interview about the pleasure in making plans to attend events, or meet other people, might be useful for analyzing the quality of life.

\section{Conclusion}

Nevertheless, the results of this study on the correlation between depression and quality of life are important. By overcoming the depression in people with SLE, the quality of life can be improved in various aspects, so that people with SLE can have a better life, despite having a chronic illness. One way in which that can be done is by they themselves recognizing the signs or symptoms of depression, and learning how to manage negative emotions or thoughts, so this management can be applied to various conditions in daily life.

\section{References}

Al Dhanhani, A. M., Gignac, M. A., Beaton, D. E., $\mathrm{Su}$, J., \& Fortin, P. R. (2014). Work factors are as- sociated with workplace activity limitations in systemic lupus erythematosus. Rheumatology, 53, 20442052. https://doi.org/10.1093/rheumatology/keu242.

Balsamo, S., Nascimento, D. C., Tibana, R. A., Santana, F. S., Mota, L. M. H., \& Santos-Neto, L. L. (2013). The quality of life of patients with lupus erythematosus influences cardiovascular capacity in 6-minute walk tests. Revista Brasileira de Reumatologia, 53 (1), 75-87.

Corder, G. W., \& Foreman, D. I. (2009). Non-parametric statistics for non-statisticians: A step-by-step approach. Hoboken, N.J: Wiley.

Devilliers, H., Amoura, Z., Besancenot, J-F., Bonnotte, B., Pasquali, J-L., Wahl, D., . . Bonithon-Kopp, C. (2014). Responsiveness of the 36-item short-form health survey and the lupus quality of life questionnaire in SLE. Rheumatology, 54, 940-949. https:// doi.org/10.1093/rheumatology/keu410.

Etchegaray-Morales, I., Mendez-Martinez, S., JimenezHernandez, C., Mendoza-Pinto, C., Alonso-Garcia, N. E., Montiel-Jarquin, A.,...Garcia-Carrasco, M. (2017). Factors associated with health-related quality of life in Mexican lupus patients, using LupusQol. Plos One, 12(1), 1-10. https://doi.org/10.13 71/journal.pone.0170209.

Gayed, M., \& Gordon, C. (2007). Pregnancy and rheumatic diseases. Rheumatology, 46, 1634-1640. https:// doi.org/10.1093/rheumatology/kem156.

Ginting, H., Näring, G., van der Veld, W. M., Srisayekti, W., \& Becker, E. S. (2013). Validating the Beck Depression Inventory-II, in Indonesia's general population and coronary heart disease patients. International Journal of Clinical and Health Psychology, 13(3), 235-242.

Hidayati, F. (2014). Ketabahan dan kecenderungan depresi pada penderita lupus. Wacana Jurnal Psikologi, 6(11), 88-102.

Kasjmir, Y. I., Handono, K., Wijaya, L. K., Hamijoyo, L., Albar, Z., Kalim, H., ... Ongkowijaya, J. A. (2011). Rekomendasi perhimpunan reumatologi Indonesia untuk diagnosis dan pengelolaan lupus eritematosus sistemik. Jakarta: Perhimpunan Reumatologi Indonesia.

Lahita, R. G., Tsokos, G., Buyon, J. P., \& Koike, T. (2011). Systemic lupus erythematosus (5th edition). California: Elsevier.

Lupus yang misterius. (2008, May 15). Sindo, Jurnalis. Retrieved from http://lifestyle.okezone.com /read/2008/05/15/27/109464/lupus-yang-misterius

McDowell, I. (2006). Measuring health: A guide to rating scales and questionnaires (3rd edition). New York: Oxford University Press. 
McElhone, K., Abbott, J., Shelmerdine, J., Bruce, I. N., Ahmad, Y., Gordon, C., ... Teh, L-S. (2007). Development and validation of a disease-specific health-related quality of life measure, the Lupus QoL, for adults with systemic lupus erythematosus. Arthritis \& Rheumatism (Arthritis Care \& Research), 57(6), 972-979. https://doi.org/10.1002/art.22881.

McElhone, K.., Abbott, J., \& Teh, L-S. (2006). A review of health related quality of life in systemic lupus erythematosus. Lupus, 15, 633-643. https:// doi.org/10.1177/0961203306071710.

McElhone, K., Castelino, M., Abbott, J., Bruce, I. N., Ahmad, Y., Shelmerdine, J., . . . Teh, L-S. (2010). The LupusQoL and associations with demographics and clinical measurements in patients with systemic lupus erythematosus. J.Rheumatol, 37(11), 22739. Abstract retrieved from https://www.ncbi.nlm. nih.gov/pubmed/20810500.

Na'im, A., \& Syaputra, H. (2010). Kewarganegaraan, suku bangsa, agama, dan bahasa sehari-hari penduduk Indonesia: Hasil sensus penduduk 2010. Jakarta: Badan Pusat Statistik.

O'Riordan, R., Doran, M., \& Connolly, D. (2017). Fatigue and activity management education for individuals with systemic lupus erythematosus. Occupational Therapy International, 2017. https://doi. org/10.1155/2017/4530104

Palagini, L., Mosca, M., Tani, C., Gemignani, A., Mauri, M., \& Bombardieri, S. (2013). Depression and sys- temic lupus erythematosus: A systemic review. $\mathrm{Lu}$ pus, 22, 409-416. https://doi.org/10.1177/096120 3313477227.

Petterson, S., Bostrom, C., Eriksson, K., Svenungsson, E., Gunnarsson, I., \& Henriksson, E. W. (2015). Lifestyle habits and fatigue among people with systemic lupus erythematosus and matched populations controls. Lupus, 24, 955-956. https://doi.org/10.1 177/0961203315572716.

Seawell, A. H., \& Danoff-Burg, S. (2005). Body image and sexuality in women with and without systemic lupus erythematosus. Sex Roles, 53, 865-876. https:// doi.org/10.1007/s11199-005-8298-y.

Shen, B., Tan, W., Feng, G., He, Y., Liu, J., Chen, W., ... Gu, Z. (2013). The correlations of disease activity, socioeconomic status, quality of life, and depression/anxiety in Chinese patients with systemic lupus erythematosus. Clinical and Developmental Immunology, 2013(2), 1-6. https://doi.org/10.115 $5 / 2013 / 270878$

Tay, S., Cheung, P., \& Mak, A. (2015). Active disease is independently associated with more severe anxiety, rather than depressive symptoms, in patients with systemic lupus erythematosus. Lupus, 24, 1392-1399. https://doi.org/10.1177/09 6120315591026.

Wallace, D. J. (2007). The lupus book: Panduan lengkap bagi penderita lupus dan keluarganya (Wiratama C., Trans.). Yogyakarta: B-First. 